\title{
A Comparative Study of the Impact of Domestic and Foreign Investment on Technological Progress of China's Manufacturing Industry
}

\author{
Ying Zhao, Jianhong Wu \\ School of Economics and Management, Beijing Jiaotong University, Beijing, China \\ 15120542@bjtu.edu.cn,wujh@bjtu.edu.cn
}

Keywords: domestic investments; foreign investments; technological progress; influence

\begin{abstract}
The paper, on the basis of research at home and abroad, analyzed the impact of the domestic investment and foreign investment on China's technological progress in manufacturing. Empirical analysis method is used in this paper.
\end{abstract}

\section{Introduction}

As the largest industrial system in our national economy, manufacturing industry is the most developed among the industrial groups, with the most detailed division of labor and the highest degree of specialization. It has constituted the most important part of our country and even the whole national economic system. It has become the foundation and pillar of the national productive capacity.

Since the reform and opening up, the rapid development of China's manufacturing industry, has now become the world's largest manufacturing power.Whether from the scale or from the technical level,China's manufacturing industry has made great success.Is this a significant increase in the level of technology is mainly the result of foreign investment, or domestic capital in the efforts of independent innovation results, or both, the two are evenly matched results?

\section{Theoretical Analysis}

2.1 Analysis of the impact of domestic investment on manufacturing technology progress. At present, the source of domestic capital into the manufacturing sector mainly private capital and state-owned capital. In promoting the upgrading of industrial technology, domestic capital mainly through the promotion and improvement of various types of high-tech parks and development zones to upgrade the manufacturing industry-related technology, capital, technology, personnel, industry and other elements or resources under the encouragement and guidance of the Government gathered, To foster high-tech manufacturing enterprises, the development of high-tech. Manufacturing investment in scientific research is the direct investment in technology to enhance the level of investment, but also as the main way to enhance technological progress.

Of course, in addition to domestic investment in R \& D investment can increase the technological progress has an important role in the other inputs can also enhance the technological progress to a certain extent enhance the role, for example, manufacturing workers of human capital investment, including labor The quality of the training and upgrading of the enterprise management of capital investment, the construction of enterprise facilities such as the improvement of transport conditions, etc., but these are not directly enhance the technological progress play a direct role, more from the Indirect way to stimulate the improvement of technological progress, and difficult to directly measure the role of technological progress to enhance the size, but in the end, these are as part of domestic investment, technological progress or directly or indirectly play a catalytic role.

2.2 Analysis of the impact of foreign investment on manufacturing technology progress. Today, multinational corporations (MNCs) are increasingly becoming the main source of technology transfer between enterprises, as the production of MNCs increasingly dominates the manufacturing industry. Multinational companies with advanced technical knowledge and rich experience in management and other assets, some of which have the property of public goods, multinational 
companies in China's manufacturing market once, they can not avoid some of their assets to other enterprises in China's manufacturing spillover, The externality, non-exclusion and non-competition of products make it possible for local manufacturing enterprises in China to learn and use these special assets of MNCs to improve their own production efficiency. At the same time, they can produce positive externalities, namely positive technology spillover effect. Different from the above, foreign investment may also contribute to the technological progress of China's manufacturing industry is not significant or even a certain degree of negative technological spillover effect, hinder the manufacturing industry to enhance technology.

\section{Empirical Analysis}

3.1 Variable Analysis. In this paper, the stochastic frontier production function model is chosen to estimate TFP.

According to the stochastic frontier production function model, the growth of total factor productivity can be decomposed into four parts under the premise of knowing the price index of manufacturing products, that is, advanced technological progress(FTP), relative technological efficiency change rate (TE), economies of scale (SE) and Configure the efficiency change (AE).That is

$$
\begin{aligned}
& \mathrm{FTP}_{\mathrm{it}}=\alpha_{\mathrm{t}}+\alpha_{t t} t+\sum \alpha_{j t} \ln \alpha_{j i t} \\
& \mathrm{TE}_{\mathrm{it}}=-\frac{d u}{d t}=\mu_{i \exp }[-\gamma(t-T)]=\mu_{i t} \\
& \mathrm{SE}_{\mathrm{it}}=(\mathrm{RTS}-1) \sum \lambda_{j} x_{j}
\end{aligned}
$$

A simplified model of the above

$$
\begin{aligned}
\mathrm{TFP} & =\mathrm{y}-x=\frac{\partial \ln f(x, t)}{\partial t}+\left(-\frac{d u}{d t}\right)+(R T S-1) \sum \lambda_{j} x_{j} \\
& =F T P+T E+S E
\end{aligned}
$$

The explanatory variables of this paper can be divided into two categories in the empirical analysis. One is the main research variables of domestic investment and foreign investment in DC and FC, the change of variables on total factor productivity effect is the main investment, including investment in fixed assets, human capital investment, investment in research and development of direct and indirect investment in manufacturing investment in domestic and foreign investment, including foreign direct investment FDI and indirect foreign investment that bonds, stocks and other forms of investment in manufacturing.the other class of explanatory variables are other effects on the manufacturing technology of the variables such as trade openness, trade openness mainly uses the import and export value accounted for the proportion of GDP to measure and manufacturing industry scale manufacturing industry annual output value is represented.

3.2 Econometrics Model Tests. Based on the stochastic frontier production function to measure the total factor productivity and other analytical research theories, the model is assumed as follows:

$$
\mathrm{TFP}=\alpha_{0}+\alpha_{1} \ln D C_{t}+\alpha_{2} \ln \mathrm{F} C_{t}+\alpha_{3} \ln M P_{t}+\alpha_{4} \mathrm{OPEN}_{t}+\alpha_{5} e_{t}
$$

Where $\alpha_{0}$ is the intercept term of the estimated model, taking the 1995 as base period, $\mathrm{t}=$ $1,2,3 \ldots .19$ represents the t-year from the base period, $\ln D C_{t}$ is the log of the domestic investment in manufacturing in year $\mathrm{t}, \alpha_{1}$ represents its coefficient. $\ln \mathrm{F} C_{t}$ is the $\log$ of the domestic investment in 
manufacturing in year $\mathrm{t}, \alpha_{2}$ represents its coefficient. $\ln M P_{t}$ is the logarithm of the value of manufacturing output in year $\mathrm{t}, \alpha_{3}$ represents its coefficient. OPEN $\mathrm{N}_{t}$ is the openness of foreign trade in year $\mathrm{t}, \alpha_{4}$ represents its coefficient. $e_{t}$ is the random disturbance term.

This paper selects the time series data from 1995 to 2013, and uses the multiple linear regression model to verify the domestic investment and foreign investment which mainly affect the technological progress of China's manufacturing industry, and measure the degree of its influence.

In order to observe whether the data is stable, we carry out unit root test on time series data domestic investment (lnDC), foreign investment (lnFC), foreign trade openness (OPEN), manufacturing output (lnMP).

Table 3.2.1 Time Series Data ADF Unit Root Test Results

\begin{tabular}{lllll}
\hline Variable & Inspection Type & ADF test & Pro value & Conclusion \\
\hline TFP & $(\mathrm{C}, \mathrm{T}, 1)$ & $12.356435^{*}$ & 0.0001 & steady \\
$\operatorname{lnFC}$ & $(\mathrm{C}, \mathrm{T}, 1)$ & $3.781021^{*}$ & 0.0000 & steady \\
$\operatorname{lnFC}$ & $(\mathrm{C}, \mathrm{T}, 1)$ & $5.837819^{*}$ & 0.0000 & steady \\
OPEN & $(\mathrm{C}, \mathrm{T}, 1)$ & $8.982672^{*}$ & 0.0003 & steady \\
$\operatorname{lnMP}$ & $(\mathrm{C}, \mathrm{T}, 1)$ & $9.239015^{*}$ & 0.0000 & steady \\
\hline
\end{tabular}

Table 3.2.2 Time Series Data PP Unit Root Test Results

\begin{tabular}{lclll}
\hline Variable & Inspection Type & PP test & Pro value & Conclusion \\
\hline TFP & $(\mathrm{C}, \mathrm{T}, 1)$ & $121.372312^{*}$ & 0.0000 & steady \\
$\operatorname{lnFC}$ & $(\mathrm{C}, \mathrm{T}, 1)$ & $213.388901^{*}$ & 0.0000 & steady \\
$\operatorname{lnFC}$ & $(\mathrm{C}, \mathrm{T}, 1)$ & $85.332114^{*}$ & 0.0000 & steady \\
OPEN & $(\mathrm{C}, \mathrm{T}, 1)$ & $283.121312^{*}$ & 0.0001 & steady \\
$\operatorname{lnMP}$ & $(\mathrm{C}, \mathrm{T}, 1)$ & $55.423571^{*}$ & 0.0000 & steady \\
\hline
\end{tabular}

From the above two tables can be seen that the two test methods are time series data test results are stationary sequence, basically can guarantee the stability of the selected sequence can be directly regression analysis.

The regression equation of the above stationary series is obtained by least squares method:

$$
\begin{aligned}
& \mathrm{TFP}=0.0723+0.418 L N \mathrm{LC}+0.382 L N \mathrm{FC}+0.002 L N \mathrm{MP}+0.103 \mathrm{OPEN}+\mathrm{e}_{t} \\
& (0.928)(47.075)(9.899)(23.958)(10.247), r^{2}=0.985
\end{aligned}
$$

$\hat{\mathrm{e}}_{t}=$ TFP $-0.0723-0.418 L N \mathrm{DC}-0.382 L N \mathrm{FC}-0.002 L N \mathrm{MP}-0.103 \mathrm{OPEN}$

The AEG test results of residual sequence are as follows:

$$
\hat{\mathrm{e}}_{t}=-0.435 \hat{\mathrm{e}}_{\mathrm{t}-1}+281 \Delta \hat{\mathrm{e}}_{\mathrm{t}-1} \quad \mathrm{R}^{2}=0.45 \mathrm{DW}=1.96
$$

From the above results, it can be concluded that there is a cointegration relationship between TFP and LNDC, LNFC, LNMP, and OPEN sequences, because the residual sequence has no autocorrelation. In the long run, variables have a positive correlation between the equilibrium relationship.

The error correction model is structured as follows:

$$
\Delta \mathrm{TFP}=\alpha+\beta_{1} \triangle \operatorname{lnDC}+\beta_{2} \triangle \operatorname{lnFC}+\beta_{3} \triangle \operatorname{lnMP}+\beta_{4} \triangle \mathrm{OPEN}+\hat{\mu}_{t-1}+\varepsilon_{t}
$$


After a variety of tests on the model, and in order to explain the variable total factor productivity and explanatory variables of domestic and foreign investment and manufacturing output, the establishment of foreign trade between the short-term and long-term effective balance between the error correction obtained after The regression equation is as follows:

$$
\begin{aligned}
& \Delta \mathrm{TFP}=0.083+0.402 \Delta L N \mathrm{DC}+0.388 \Delta L N \mathrm{FC}+0.001 \Delta L N \mathrm{MP}+0.113 \Delta \mathrm{OPEN}+0.047 \mathrm{e}_{t} \\
& (0.783)(12.023)(5.240)(13.422)(2.591)(1.934), r^{2}=0.972
\end{aligned}
$$

The above results indicate that the TFP of explanatory variables is related to the explanatory variables of domestic investment, foreign investment, manufacturing output and foreign trade openness, and all of them are positive correlations. TFP is not only dependent on the explanatory variables of domestic investment, foreign investment, manufacturing output, foreign trade openness, but also on the previous period of domestic investment, foreign investment, manufacturing output, external Trade openness These explanatory variables deviate from the equilibrium level.

\section{Conclusion}

The empirical results of the domestic and foreign investment on the level of technological progress of the 19 years data from 1995 to 2013 are verified by the time series data model, which validates the theoretical expectation of this paper. Overall, the technological progress of China's manufacturing industry mainly comes from domestic investment and foreign investment, at the same time by the domestic investment and foreign investment double impact. Among them, foreign direct investment (FDI) is the main form and source of foreign investment. Technology spillovers are promoted by technology introduction and demonstration effect, competitive effect, correlation effect and human capital flow effect of foreign capital. The investment also enhances the independent research and development capability, core competitiveness and promotes the technological progress of the enterprise by increasing the $\mathrm{R} \& \mathrm{D}$ investment of enterprises and other means to expand the reproduction mode.

Otherwise, domestic investment and foreign investment have greater impact on technological progress than foreign investment, although the gap between domestic and foreign investment is not particularly significant.

\section{References}

[1] Aigner D L, Lovell C A K, Schmidt P. Formulation and Estimation of Stochastic Frontier Production Models[J]. Journal of Econometrics,1997,6(1):21-37.

[3] Blomstrem M,Wolf E. Multinational corporational and productivity convergence in Mexico[M].Oxford University Press,2008:115-135.

[4] Chang S J, Xu D.Spillovers and competition among foreign and local firms in China[J].Strategic Management Journal,2008(29):495-518.

[5] Findlay R.Relative Backwarness. Direct Foreign Investment and the Transfer of Technology:A Simple Dynamic Model[J]. Quarterl Journal of Economics, 2009(9):116-121.

[6] Kumbhakar S C. Estimation and Decomposition of Productivity Change When Production Is Not Efficient: A Panel Data Approach[J]. Econometric Reviews,2000,19(4):425-460.

[7] Meeusen W, Van Den Broeck J. Efficiency Estimation From Cobb-Douglas Prodution Functions With Composed Error[J]. International Economic Review,1997,18(2):435-444. 